\title{
The importance of endophyte in agricultural systems - changing plant and animal productivity
}

\author{
H S EASTON $^{1}$ and L.R. FLETCHER ${ }^{2}$ \\ ${ }^{1}$ AgResearch Grasslands, Private Bag 11008, Palmerston North, New Zealand \\ ${ }^{2}$ AgResearch, PO Box 60, Lincoln, New Zealand \\ syd.easton@agresearch.co.nz
}

\begin{abstract}
Infection of tall fescue and ryegrass pastures with Neotyphodium endophytes are of much greater interest in New World pastures than in Europe where they have been present as long as agriculture itself. This paper presents an overview of the importance of endophyte infection in pastures, enhancing the productivity and persistence of their hosts, both directly and through protection from invertebrate pressure, the biological factors behind this importance and the measures available to profit from the advantages of endophyte infection while palliating the negative effects.
\end{abstract}

Keywords: tall fescue, ryegrass, livestock, edaphic stress, invertebrate pests

\section{Introduction}

The initial interest in Neotyphodium endophytes in grasses focused on intensively managed pastures of tall fescue (Festuca arundinacea) and perennial ryegrass (Lolium perenne). Study of meadow fescue (F. pratensis) (Gams et al. 1990) and Italian ryegrass (L. multiflorum) (Latch et al. 1988) came later, while research on adventitious grasses has intensified in parallel to the interest in agricultural species (Faeth et al. 2004; Pan \& Clay 2002). It is immediately interesting that the intense interest in ryegrass and tall fescue began (and largely remains) in the New World, where these species are relatively recent introductions.

Perennial ryegrass is identified as a grass that has specifically evolved as adapted to the intensive grazing associated with domesticated livestock, and spread across Europe with farmers and their animals (Balfourier et al. 2000). Tall fescue is closely related to it (Darbyshire \& Warwick 1992; Jenkin 1933), and their respective endophyte symbionts are regarded as more recently evolved than those of the annual ryegrasses (Moon et al. 2000).

\section{Tall Fescue and Perennial Ryegrass in Intensive Livestock Agriculture}

The establishment of a widespread tall fescue grazing resource in USA is credited to the development of the cultivar 'Kentucky 31 ' (Ball et al. 1993). This one source accounts for the tall fescue that spread in the second quarter of $\mathrm{C} 20^{\text {th }}$ across huge areas in southeast and central west USA, much of which had soils severely degraded by intensive row cropping. These pastures were (are) intensively infected with endophyte, accounting for the toxicosis that became a growing concern (Bush \& Buckner 1973; Yates 1962) and probably also for the difficulty faced by plant breeders in producing improved cultivars that could match 'Kentucky 31 ' in robustness and persistence.

With the identification of endophyte ( $N$. coenophialum) as the source of the toxins responsible for fescue toxicosis (Bacon et al. 1977), "Fungus-free Fescue" was promoted as a safe forage and the answer to the limitations of livestock productivity on fescue pastures. This soon proved to be a false hope as farmer experience and research results (Read \& Camp 1986) established that the robustness and persistence that were the hallmarks of fescue pasture had been lost (Ball et al. 1993).
Perennial ryegrass pastures have been widespread in New Zealand (NZ) since the last quarter of $\mathrm{C} 19^{\text {th }}$ and cannot be traced to any one source. Grass seed from the British Isles, including perennial ryegrass, was first sown in early $\mathrm{C} 19^{\text {th }}$ (Stewart 2006) and significant seed imports continued for the rest of that century, from both the British Isles and Australia. Grass seed harvested in the drier regions of Canterbury and Hawkes Bay became a significant source for new pastures from the $1880 \mathrm{~s}$. A certified seed system became operative from 1929 , after superior locally grown sources were identified (Levy \& Davies 1929), and an improved bred strain of perennial ryegrass became available from 1930 . This was continually reselected and improved, accounted for a large proportion of seed used in NZ for the next four decades, and was infected with endophyte. Most old ryegrass pastures in NZ are intensively infected with endophyte (Latch \& Christensen 1982; Widdup \& Ryan 1992).

As for tall fescue, when $N$. lolii was identified as responsible for ryegrass staggers (Fletcher \& Harvey 1981), it was proposed that endophyte-free ryegrass would end the problem. This was not tried on-farm, as within months it was shown (Prestidge \& Gallagher 1988; Prestidge et al. 1982) that endophyte provided protection against Argentine stem weevil (Listronotus bonariensis), which at the time was probably the highest profile pasture pest in NZ.

The interest in Argentine stem weevil had been heightened by farmer experience and research that closely-related ryegrass cultivars differed radically in their tolerance of this pest (Kain et al. 1982). It was soon shown that while nucleus seed of both cultivars was infected with endophyte, the percentage infection of seed found in commerce differed significantly, reflecting their commercialisation history. Hindsight then showed there had been a history of new cultivars carrying a high frequency of infection, and remaining that way while demand ran ahead of seed supply, so that seed was cleaned and sold within weeks of harvest. Once initial demand was satisfied, seed began to be held over at least a year, and endophyte infection declined. Infrequent multiplication of high-grade seed and use of old high-grade seed exacerbated the problem (M.P. Rolston, pers. comm.). Subsequent new cultivars, with high levels of infection, were then compared with controls carrying lower levels, and appeared artificially good.

Later studies have identified several other invertebrate herbivores that can severely affect endophyte-free ryegrass in NZ, but which are deterred by endophyte-infection (Pennell et al. 2005; Popay \& Bonos 2005; Prestidge et al. 1994). Further, endophyte toxins deter grazing ruminants (the toxicoses regarded as the down-side of endophyte-infection), so that infected grass is grazed less intensively (less frequently and not as close to the ground and the leaf meristems) than infected swards (Edwards et al. 1993). Infected swards are thus protected from debilitating over-grazing.

\section{Endophyte and Ecological History}

Tall fescue pastures in USA and ryegrass pastures in NZ are probably typical of the situation elsewhere in the New World. In 
Australia, endophyte infection is widespread in ryegrass pastures (Cunningham et al. 1993; Reed et al. 2005), although there is not usually the immediate pest-driven collapse of endophyte-free pastures sometimes seen in NZ.

Results from Europe are different. Some studies have found little endophyte, and when endophyte is reported as significantly present (Oliveira \& Castro 1997), frequency is typically lower than found in NZ (Widdup \& Ryan 1992). Some studies have found no advantage to endophyte-infected plants or swards while others have found modest advantages (Lewis et al. 1997; Ravel et al. 1995).

The situation of perennial ryegrass in Europe is a longestablished equilibrium, as old as agriculture in that continent (Balfourier et al. 2000), in climate and soil zones to which it is adapted, and with buffered impact of invertebrate pests. In temperate northern Europe, where ryegrass monocultures are established, the climate and management regimes are very non-stressful for ryegrass, and in regions where climate is more stressful, the swards tend to be more complex mixtures. Frequency of endophyte infection in old European perennial ryegrass swards has been related to edaphic stress (Lewis et al. 1997; Ravel et al. 1997a), but not to the extent that infected swards persist while newly-sown endophyte-free swards collapse within 2 years. In NZ, there is, in many situations, a near mono-culture of ryegrass and an invertebrate fauna in which some pests enjoy little natural control so that they can quickly destroy an endophyte-free sward. Endophyte, present in perennial ryegrass seed imported from Europe, has greatly increased in infection frequency under these selective pressures. Where the biological control agent against Argentine stem weevil (Microctonus hyperodae) has successfully established, the advantage of endophyte-infected ryegrass has become less obvious (Barker \& Addison 2006; Goldson et al. 1995).

Some pasture pests have been identified as deterred by endophyte in tall fescue, but most authors attribute the greater persistence and productivity of infected swards in USA to enhanced tolerance of edaphic stress (Malinowski et al. 2005; Read \& Camp 1986). Different experiments have associated tolerance of water stress with a number of mechanisms such as leaf rolling, stomatal closure, osmotic adjustment, accumulation of sugar alcohols and phyto-hormone status (Bacon 1993; Elbersen \& West 1996; Richardson et al. 1992; Richardson et al. 1993; West et al. 1993). Greater tolerance of sub-optimal soil nutrient status has also been documented (Malinowski et al. 2000). There has been less European work on tall fescue endophyte than for ryegrass, but it is clear that endophyte-free tall fescue is widely regarded as robust in pastures. Perhaps summer-active tall fescue is being used in USA in zones with greater summer temperatures and drought stress than are encountered in non-Mediterranean Europe. In the Mediterranean region, grasses in old swards are summer-dormant.

The pastures of the New World thus expose tall fescue and perennial ryegrass to edaphic stress and pest attack at greater intensity than typically encountered in the longer-established situations in Europe. In many respects, the incidence and impact of endophyte in tall fescue and perennial ryegrass pastures in Europe is more similar to that of natural ecosystems, where ecological advantage is less immediately evident (Faeth 2002), than to the managed pastures of the New World.

\section{Growth and Productivity of Pastures}

As noted above, endophyte-infected swards in NZ and USA have been shown to sometimes offer radically greater persistence and productivity than endophyte-free controls. In NZ ryegrass swards this is usually associated with invertebrate pest activity. Endophyte-free swards sometimes collapse under pest pressure (Barker et al. 1984), and even without total death, productivity is affected. In a network of trials over six sites, herbage yield of endophyte-infected ryegrass was greater than that of endophytefree controls. In summer and autumn the mean difference over 3 years was 20 and 30\% respectively (Popay et al. 1999). The usual outcome of insect pressure is that the sward component that is endophyte-infected, even if initially small, increases and becomes dominant (Francis \& Baird 1989; Hume \& Brock 1997). The instability of endophyte-free pastures, contaminated and then moving quickly to infected status, is a feature of both ryegrass and tall fescue (Hume \& Barker 2005).

Direct enhancement of ryegrass growth and tolerance of edaphic stress has been documented (Latch et al. 1985; Ravel et al. 1997b), but while frequency of endophyte infection in ryegrass has been related to edaphic stress in France (Lewis et al. 1997), the effect of invertebrate pests is the over-riding effect in New Zealand, and is difficult to eliminate from experiments. There have been reports that in the absence of any invertebrate pest pressure, endophyte-infection may impose a cost on the host plant (Keogh \& Lawrence 1987), but there is no evidence that such a cost is ever a factor in a field situation. There is evidence of poor clover performance associated with high endophyte frequency in the ryegrass component of a sward, with some data suggesting a direct effect not accounted for by grass vigour (Sutherland \& Hoglund 1989). If such an effect could be substantiated, farmers in mild regions with minimal invertebrate pest pressure (such as in the south of NZ) might be better using endophyte-free swards. However, this proposed advantage to endophyte-free swards has not been substantiated on a field scale (Eerens et al. 1998).

In NZ, endophyte-free tall fescue usually persists, but does sometimes succumb, particularly under pressure from African black beetle (Heteronychus arator), and research has shown significant persistence and yield advantages associated with infection (Cooper et al. 2002; Easton \& Cooper 1997). Tall fescue pastures in USA have usually proved non-viable without endophyte infection (Read \& Camp 1986), particularly in the South. Where milder temperatures or very careful management succeeds in maintaining persistence, yield is affected. Endophyte infection makes a large positive contribution to herbage available to livestock from tall fescue pastures.

\section{Toxicoses}

Tall fescue has long been known to be toxic (Cunningham 1948) and the physiology of toxicosis has been intensively researched (Oliver 1997; Oliver 2005; Spiers et al. 2005). The most evident physiological effect is the disruption of the animals' thermoregulatory control, and most health and productivity effects can be ascribed to this. Ergopeptine alkaloids are the active factors responsible (Yates et al. 1985), but whether the primary products present in herbage or derivatives of them are directly involved is not yet clear (Hill et al. 2001). Minor components present in herbage may specifically contribute (Gadberry et al. 1997).

Productivity losses associated with tall fescue toxicosis have been well documented (Thompson et al. 1993). A summary of ten trials in different states of USA showed a mean $37.5 \%$ loss in liveweight gain on endophyte-infected tall fescue (Schmidt \& Osborn 1993). Grazing intake is depressed in affected animals, and in some trials this effect is enough to account for productivity impacts (Schmidt \& Osborn 1993).

Research has documented more than $40 \%$ impairment in 
fertility (Gay et al. 1988), and 60\% in milk production (Hemken et al. 1979). Animals occasionally die. "Fescue foot" is a severe effect, requiring the immediate slaughter of affected animals. The effects on pregnant mares (Cross 1997) can be appalling.

Ryegrass staggers, first observed in the $1880 \mathrm{~s}$, has been clinically described, and a quantitative scale developed for research comparisons (Keogh 1973). An early suggestion associating ryegrass staggers (and tall fescue toxicosis) with Neotyphodium endophyte was discounted (Cunningham 1958). After the association with ryegrass endophyte was established (Fletcher 1982; Fletcher \& Harvey 1981), the primary active factor, lolitrem B, was described (Gallagher et al. 1984).

Further research showed that clinical ryegrass staggers were not the only negative effect on livestock. Liveweight gain, herbage intake, body temperatures, respiration rate, faecal moisture content and, in sheep, the accumulation of faecal contamination (and associated fly-strike) are all affected (Easton \& Couchman 1999; Fletcher et al. 1999; Reed et al. 2005; Watson et al. 1999). There has been one report of severe effects on lamb survival (Cunningham et al. 1993). Ergovaline was shown to be present in infected ryegrass herbage, not at the concentrations documented for tall fescue, but in the range to be physiologically active (Easton et al. 1993; Rowan \& Shaw 1987).

Dairy cows are less often visibly affected by ryegrass staggers than sheep, and in several short-term comparisons (Thom et al. 1999) there was little evidence of impaired milk production. However, studies through whole seasons have shown effects up to $15 \%$ over a full lactation, and of $20 \%$ or more in late summer and autumn (Bluett et al. 2005; Bluett et al. 2003; Ussher 2003). A recent intensive trial with controlled feeding has also shown impairment of milk production (Thom 2007).

A number of veterinary reports from northern NZ (Brookbanks et al. 1985) describe heat stress in cattle similar to fescue toxicosis. This did not appear to be associated with the presence on farms of adventitious tall fescue (Kearns 1986), and it was argued that ergovaline in ryegrass pastures could account for the symptoms (Easton et al. 1996). However, endophyte status of ryegrass has not affected body temperatures or incidence of heat stress in controlled experiments with cattle (Bluett et al. 2005; Easton \& Couchman 1999).

On farms, ryegrass staggers can vary from an irritant, impeding efficient movement of animals, to catastrophic episodes making normal farm operations impossible (Milne et al. 1999). In Australia there have been documented episodes of widespread livestock death from ryegrass endophyte toxicosis (Cunningham et al. 1993; Reed et al. 2005).

While most research and experience is with herbage grazed in situ, there have been many documented cases of ryegrass and fescue toxicosis arising from the consumption of hay made from endophyte-infected herbage. Ergovaline and lolitrem persist in dried and ensiled herbage (Clark et al. 1996; Fletcher 2005; Hume et al. 2007; Roberts et al. 2002). However, activity does decay with time, particularly for ergovaline, so that hay can be stock-piled if necessary. Hay is used away from farms, and expensive horses and zoo animals (Bluett et al. 2004; Essen et al. 1995) have been affected with ryegrass staggers.

Concentrations of toxins in infected herbage varies through the season (Fletcher et al. 2000b; Reed et al. 2001), with the part of the plant and thus in the pasture profile (Keogh \& Tapper 1993; Musgrave 1984), and with the genetics of the host (Agee \& Hill 1994; Easton et al. 2002). Plant status of nitrogen and other nutrients also affects toxin concentrations. Controlled experiments have documented depression of toxin concentrations at higher levels of nitrogen nutrition (Hunt et al. 2005; Rasmussen et al. 2007) that could not be accounted for by dilution effects, but increased concentrations with application have also been reported (Lane et al. 1997), and higher concentrations of mycelium in leaf were associated with urine patches (Keogh 1986), which were also more intensively grazed. This multi-dimensional variation makes toxin levels and toxicosis outbreaks difficult to predict. Toxin intake by livestock can not be tightly controlled, but grazing management that avoids sustained grazing into old tissue close to the ground, and encourages fresh regrowth without excessive nitrogen peaks will reduce the risk of exposure (Fletcher 2005).

\section{Endophyte and the Seed Industry}

The discovery of the importance of endophyte, and then of the influence of seed harvest and management practice on endophyte viability (Hare et al. 1990; Rolston et al. 1986; Welty et al. 1987) had immediate implications for the seed industry. An early response was to add value to inventory by delivering seed to defined specification, with either high or very low incidence of endophyte infection according to the need of a market niche. Seed industry partners have been essential contributors in delivering to market selected endophyte strains with known properties, and have upgraded seed stand agronomy, harvest and cleaning practice and inventory management (Green \& McKenzie 1999; Rolston \& Agee 2007). In USA, one company has been primarily responsible, but in NZ, all proprietary herbage seed companies have been involved.

An associated industry handles and markets straw from ryegrass and tall fescue seed stands (including straw from turf grass cultivars). Ergovaline and lolitrem B persist in straw, and their presence negatively affects the value of this by-product (Miyazaki et al. 2001; Stamm et al. 1994; Welty et al. 1994).

\section{Selected Endophyte}

Development of endophyte strains that do not produce alkaloids toxic to livestock was first proposed by Latch (Latch 1989; Latch 1994), and identification of selected strains and their release to livestock farmers through the seed industry have been discussed at earlier Symposia (Bouton \& Easton 2005; Fletcher \& Easton 1997; Fletcher \& Easton 2000). The advantages in health and productivity of livestock grazing herbage infected with selected endophyte in research trials have been well documented (Bouton et al. 2000; Bouton et al. 2002; Fletcher 1999; Fletcher et al. 2000a; Fribourg et al. 2002; Parish et al. 2003a; Parish et al. 2003b; Watson et al. 2004). These strains have also proved to be good research tools, allowing determination of the negative effects accumulated over time of the toxic strains typically present in pastures. Such longer term studies were difficult to achieve using endophyte-free controls.

On farm, results have been excellent. Use of Max-Q ${ }^{\circledR}$ in USA has been constrained by the small size of many herds and the fact that many farmers rely on off-farm income, so that they are risk-averse. Nevertheless, many thousands of acres of toxic tall fescue have been converted to Max-Q pastures, with regular repeat orders as areas on individual farms are extended. All this contributes to profitability. In NZ and Australia, sown tall fescue pastures have historically been endophyte-free (Easton et al. 1994), but the persistence and yield advantages of infection with selected endophyte are already attracting farmers and are expected to greatly extend the value of tall fescue in these markets (Cooper et al. 2002; Wheatley et al. 2003).

AR1 endophyte (producing peramine but not ergovaline or lolitrem B) accounts for most endophyte-infected proprietary 
perennial and hybrid ryegrass cultivars sold in NZ. Any displacement of AR1 is by alternative selected endophyte strains that are more recently available (Hume et al. 2004). AR1 provides less robust protection against black beetle than commonly occurring toxic endophyte in northern NZ (Popay \& Baltus 2001), so that options for improvement are actively sought. In fact, AR1 pastures have proved to be more robust on farm than was expected, and uptake has been comprehensive, even in the north of the country where insect pressure might have compromised its success. In Australia too, uptake of ryegrass infected with selected endophyte has been excellent and continues to grow (Evans 2007).

Just as the seed industry has adapted practice to deliver selected endophyte to specification (see above), livestock farmers have had to adapt their practice. Seed can not be stored for months on farm, delivery needs to be immediately prior to sowing. Protocols for preparing fields for sowing, and managing young pastures to properly kill the old sward and avoid contamination with infected plants have been developed (Bluett et al. 2001; Hume 1999) and actively promoted. Care needs to be taken not to feed out hay from another source onto pasture infected with selected endophyte. Livestock free of the effects of toxicosis will graze closer to the ground (Edwards et al. 1993) so that farmers need to exercise care to avoid over-grazing.

However, the evidence suggests that while AR1 has successfully displaced toxic endophyte from new pastures sown, its availability has not persuaded farmers to replace old pastures if they were not going to do that as part of normal farm practice. It is estimated that only $5 \%$ of NZ pasture is replaced per year. Ryegrass pastures that can be readily cultivated are only a part of the remaining 95\% (Field 1989), but even allowing for that, the NZ farming industry is well short of achieving the readily available potential gains from freeing livestock from the pernicious effects of endophyte toxins.

\section{REFERENCES}

Agee, C.S.; Hill, N.S. 1994. Ergovaline variability in Acremoniuminfected tall fescue due to environment and plant genotype. Crop Science 34: 221-226.

Bacon, C.W. 1993. Abiotic stress tolerances (moisture, nutrients) and photosynthesis in endophyte-infected tall fescue. Agriculture, Ecosystems and Environment 44: 123-141.

Bacon, C.W.; Porter, J.K.; Robbins, J.D.; Luttrell, E.S. 1977. Epichloë typhina from toxic tall fescue grasses. Applied Environmental Microbiology 34: 576-581.

Balfourier, F.; Imbert, C.; Charmet, G. 2000. Evidence of a phylogeographic structure in Lolium species related to the spread of agriculture in Europe. A cpDNA study. Theoretical and Applied Genetics 101: 131-138.

Ball, D.M.; Pederson, J.F.; Lacefield, G.D. 1993. The tall-fescue endophyte. American Scientist 81: 370-379.

Barker, G.M.; Addison, P.J. 2006. Early impact of endoparasitoid Microctonus hyperodae (Hymenoptera: Braconidae) after its establishment in Listronotus bonariensis (Coleoptera: Curculionidae) populations of northern New Zealand pastures. Journal of Economic Entomology 99: 273-287.

Barker, G.M.; Pottinger, R.P.; Addison, P.J. 1984. Effect of Argentine stem weevil on productivity of grasses in the Waikato. New Zealand Journal of Agricultural Research 27: 93-102.

Bluett, S.J.; Burggraaf, V.T.; Hume, D.E.; Tapper, B.A.; Thom, E.R. 2001. Establishment of ryegrass pastures containing a novel endophyte. Proceedings of the New Zealand Grassland
Association 63: 259-265.

Bluett, S.J.; Hume, D.E.; Tapper, B.A.; Stephens, S.L. 2004. Incidence of ryegrass staggers in white rhinoceros (Ceratotherium simum) at Auckland Zoo. New Zealand Veterinary Journal 52: 48.

Bluett, S.J.; Thom, E.R.; Clark, D.A.; Macdonald, K.A.; Minneé, E.M.K. 2005. Effects of perennial ryegrass infected with either AR1 or wild endophyte on dairy production in the Waikato. New Zealand Journal of Agricultural Research 48: 197-212.

Bluett, S.J.; Thom, E.R.; Clark, D.A.; Macdonald, K.A.; Minnée, E.M.K. 2003. Milksolids production from cows grazing perennial ryegrass containing AR1 or wild endophyte. Proceedings of the New Zealand Grassland Association 65: 83-90.

Bouton, J.H.; Easton, H.S. 2005. Endophytes in forage cultivars. pp. 327-340. In: Neotyphodium in Cool-Season Grasses. Eds. Roberts, C. A.; West, C. P.; Spiers, D. E. Blackwell, Ames, IA.

Bouton, J.H.; Hill, N.S.; Hoveland, C.S.; McCann, M.A.; Thompson, F.N.; Hawkins, L.L.; Latch, G.C.M. 2000. Performance of tall fescue cultivars infected with non-toxic endophytes. pp. 179-185. In: Proceedings of the Grassland Conference 2000 - 4th International Neotyphodium/Grass Interactions Symposium. Eds. Paul, V. H., Dapprich, P.D. Universität-Gesamthochschuhle Paderborn, Abteilung Soest, Fachbereich Agrarwirtschaft.,

Bouton, J.H.; Latch, G.C.M.; Hill, N.S.; Hoveland, C.S.; McCann, M.A.; Watson, R.H.; Parish, J.A.; Hawkins, L.L.; Thompson, F.N. 2002. Re-infection of tall fescue cultivars with non-ergot alkaloid producing endophytes. Agronomy Journal 94: 567-574.

Brookbanks, E.O.; Bell, K.C.; Fraser, D.; Kearns, M.P.; Sutherland, R.J. 1985. Hyperthermia in cattle associated with tall fescue (Festuca arundinacea). New Zealand Veterinary Journal 33: 57-58.

Bush, L.; Buckner, R.C. 1973. Tall fescue toxicity. pp. 99-112. In: Anti-quality components of forages. Ed. Matches, A. G. Crop Science Society of America, Madison, WI.

Clark, D.A.; Thom, E.R.; Waugh, C.D. 1996. Milk production from pastures and pasture silage with different levels of endophyte infection. Proceedings of the New Zealand Society of Animal Production 56: 292-296.

Cooper, B.M.; Easton, H.S.; Hume, D.E.; Popay, A.J.; Baird, D.B. 2002. Improved performance in Northland New Zealand of tall fescue with a selected endophyte. pp. 379-381. In: 12th Australasian Plant Breeding Conference. Eds. McComb, J. A. Australasian Plant Breeding Association, Perth, WA.

Cross, D.L. 1997. Fescue toxicosis in horses. pp. 289-309. In: Neotyphodium/Grass Interactions. Eds. Bacon, C. W.; Hill, N. S. Plenum Press, New York.

Cunningham, I.J. 1948. Tall fescue grass is poison for cattle. New Zealand Journal of Agriculture 77: 519.

Cunningham, I.J. 1958. Non-toxicity to animals of ryegrass endophyte and other endophytic fungi of New Zealand grasses. New Zealand Journal of Agricultural Research 1: 489-497.

Cunningham, P.J.; Foot, J.Z.; Reed, K.F.M. 1993. Perennial ryegrass (Lolium perenne) endophyte (Acremonium lolii) relationships: the Australian experience. Agriculture, Ecosystems and Environment 44: 157-168.

Darbyshire, S.J.; Warwick, S.I. 1992. Phylogeny of North American Festuca (Poaceae) and related genera using chloroplast DNA restriction site variation. Canadian Journal of Botany 70: 2415-2429. 
Easton, H.S.; Cooper, B.M. 1997. Field performance of tall fescue with low infection with Neotyphodium endophyte. pp. 251-253. In: Neotyphodium/Grass Interactions. Eds. Bacon, C. W.; Hill, N. S. Plenum Press, New York \& London.

Easton, H.S.; Couchman, J.N. 1999. Ryegrass endophyte and cattle growth in Northland. pp. 57-62. In: Ryegrass Endophyte: An Essential New Zealand Symbiosis. Grassland Research and Practice Series 7. New Zealand Grassland Association.

Easton, H.S.; Lane, G.A.; Tapper, B.A. 1993. Ergovaline in endophyte-infected ryegrass pastures. New Zealand Veterinary Journal 41: 214.

Easton, H.S.; Lane, G.A.; Tapper, B.A.; Keogh, R.G.; Cooper, B.M.; Blackwell, M.; Anderson, M.; Fletcher, L.R. 1996. Ryegrass endophyte-related heat stress in cattle. Proceedings of the New Zealand Grassland Association 57: 37-41.

Easton, H.S.; Latch, G.C.M.; Tapper, B.A.; Ball, O.J.-P. 2002. Ryegrass host genetic control of concentrations of endophytederived alkaloids. Crop Science 42: 51-57.

Easton, H.S.; Lee, C.K.; Fitzgerald, R.D. 1994. Tall fescue in Australia and New Zealand. New Zealand Journal of Agricultural Research 37: 405-417.

Edwards, G.R.; Lucas, R.J.; Johnson, M.R. 1993. Grazing preference for pasture species by sheep is affected by endophyte and nitrogen fertility. Proceedings of the New Zealand Grassland Association 55: 137-141.

Eerens, J.P.J.; Lucas, R.J.; Easton, H.S.; White, J.G.H.; Miller, K.B. 1998. Influence of the ryegrass endophyte (Neotyphodium lolii) in a cool-moist environment. III Interaction with white clover. New Zealand Journal of Agricultural Research 41: 201-207.

Elbersen, H.W.; West, C.P. 1996. Growth and water relations of field-grown tall fescue as influenced by drought and endophyte. Grass and Forage Science 51: 333-342.

Essen, G.J.v.; Blom, M.; Gremmels Gehrmann, J.F.; Van Essen, G.J. 1995. Ryegrass staggers in horses. Tijdschrift voor Diergeneeskunde 120: 710-711.

Evans, J.W. 2007. Commercialisation of AR1 in Australia. These Proceedings

Faeth, S.H. 2002. Are endophytic fungi defensive plant mutualists? Oikos 98: 25-36.

Faeth, S.H.; Helander, M.L.; Saikkonen, K.T. 2004. Asexual Neotyphodium endophytes in a native grass reduce competitive abilities. Ecology Letters 7: 304-313.

Field, T.R.O. 1989. Vegetational survey of managed pastures in New Zealand. pp. 1407-1408. In: Proceedings of the XVI International Grassland Congress Nice, France.

Fletcher, L.R. 1982. Observations of ryegrass staggers in weaned lambs grazing different ryegrass pastures. New Zealand Journal of Experimental Agriculture 10: 203-207.

Fletcher, L.R. 1999. «Non-toxic» endophytes in ryegrass and their effect on livestock health and production. pp. 111139. In: Ryegrass Endophyte: An Essential New Zealand Symbiosis. Grassland Research and Practice Series 7. New Zealand Grassland Association.

Fletcher, L.R. 2005. Managing ryegrass-endophyte toxicoses. pp. 229-241. In: Neotyphodium in Cool-Season Grasses. Eds. Roberts, C.A.; West, C.P.; Spiers, D.E. Blackwell, Ames, IA.

Fletcher, L.R.; Easton, H.S. 1997. The evaluation and use of endophytes for pasture improvement. pp. 209-227. In: Neotyphodium/Grass Interactions. Eds. Bacon, C.W.; Hill, N.S. Plenum Press, New York \& London.

Fletcher, L.R.; Easton, H.S. 2000. Using endophytes for pasture improvement in New Zealand. pp. 149-162. In: Proceedings of the Grassland Conference 2000 - 4th International Neotyphodium/ Grass Interactions Symposium. Eds. Paul, V. H.; Dapprich, P. D. Universität-Gesamthochschle Paderborn, Abteilung Soest, Fachbereich Agrarwirtschaft, Soest, Germany.

Fletcher, L.R.; Fletcher, C.G.; Sutherland, B.L. 2000a. The health and performance of sheep grazing a non-toxic tall fescue endophyte association. pp. 459-464. In: Proceedings of the Grassland Conference 2000 - 4th International Neotyphodium/ Grass Interactions Symposium. Eds. Paul, V. H.; Dapprich, P. D. Universität-Gesamthochschle Paderborn, Abteilung Soest, Fachbereich Agrarwirtschaft, Soest, Germany.

Fletcher, L.R.; Harvey, I.C. 1981. An association of a Lolium endophyte with ryegrass staggers. New Zealand Veterinary Journal 29: 185-186.

Fletcher, L.R.; Lane, G.A.; Baird, D.B.; Davies, E. 2000b. Seasonal variations of alkaloid concentrations in two perennial ryegrass - endophyte associations. pp. 535-541. In: Proceedings of the Grassland Conference 2000 - 4th International Neotyphodium/ Grass Interactions Symposium. Eds. Paul, V. H.; Dapprich, P. D. Universität-Gesamthochschle Paderborn, Abteilung Soest, Fachbereich Agrarwirtschaft, Soest, Germany.

Fletcher, L.R.; Sutherland, B.L.; Fletcher, C.G. 1999. The impact of endophyte on the health and productivity of sheep grazing ryegrass-based pastures. pp. 11-17. In: Ryegrass Endophyte: An Essential New Zealand Symbiosis. Grassland Research and Practice Series 7. New Zealand Grassland Association.

Francis, S.M.; Baird, D.B. 1989. Increase in the proportion of endophyte-infected perennial ryegrass plants in overdrilled pastures. New Zealand Journal of Agricultural Research 32: 437-440.

Fribourg, H.A.; Waller, J.C.; Latch, G.C.M.; Fletcher, L.R.; Easton, H.S.; Stratton, A.E. 2002. Evaluation under grazing of Festuca arundinacea cultivars infected with nontoxic endophytes. pp. 530-531. In: Proceedings of the 19th Congress of the European Grassland Federation. La Rochelle, France.

Gadberry, M.S.; Denard, T.M.; Spiers, D.E.; Piper, E.L. 1997. Ovis aries: a model for studying the effects of fescue toxins on animal performance in a heat-stress environment. pp. 429431. In: Neotyphodium/Grass Interactions. Eds. Bacon, C.W.; Hill, N.S. Plenum Press, New York \& London.

Gallagher, R.T.; Hawkes, A.D.; Steyn, P.S.; Vleggaar, R. 1984. Tremorgenic neurotoxins from perennial ryegrass causing ryegrass staggers disorder of livestock: structure and elucidation of lolitrem B. Journal of the Chemical Society, Chemical Communications: 614-616.

Gams, W.; Petrini, O.; Schmidt, D. 1990. Acremonium uncinatum, a new endophyte in Festuca pratensis. Mycotaxon 37: 67-71.

Gay, N.; Boling, J.A.; Dew, R.; Miksch, D.E. 1988. Effects of endophyte-infected tall fescue on beef cow-calf performance. Applied Agricultural Research 3: 182-186.

Goldson, S.L.; Barker, G.M.; Lomas, J. 1995. Update on Argentine stem weevil biological control. pp. 42-46. In: Proceedings 47th Ruakura Dairy Farmers' Conference held at Ruakura, Hamilton, New Zealand, 13 June 1995.

Green, W.; McKenzie, J. 1999. Selected endophyte: seed industry intentions. pp. 141-142. In: Ryegrass Endophyte: An Essential New Zealand Symbiosis. Grassland Research and Practice Series 7. New Zealand Grassland Association.

Hare, M.D.; Rolston, M.P.; Christensen, M.J.; Moore, K.K. 1990. Viability of Lolium endophyte fungus in seed, and germination of Lolium perenne seed during five years of storage. pp. 147-149. In: Proceedings of the International Symposium on Acremonium/Grass Interactions. Eds. Quisenberry, S. S.; 
Joost, R. E. Lousiana Agricultural Experiment Station, New Orleans, USA.

Hemken, R.W.; Bull, L.S.; Boling, J.A.; Kane, E.; Bush, L.P.; Buckner, R.C. 1979. Summer fescue toxicosis in lactating dairy cows and sheep fed experimental strains of ryegrass-tall fescue hybrids. Journal of Animal Science 49: 641-646.

Hill, N.S.; Thompson, F.N.; Stuedemann, J.A.; Rottinghaus, G.W.; Ju, H.J.; Dawe, D.L.; Hiatt, E.E., III 2001. Ergot alkaloid transport across ruminant gastric tissues. Journal of Animal Science 79: 542-549.

Hume, D.E. 1999. Establishing and maintaining a toxin-free pasture: a review. pp. 123-132. In: Ryegrass Endophyte: An Essential New Zealand Symbiosis. Grassland Research and Practice Series 7. New Zealand Grassland Association.

Hume, D.E.; Barker, D.J. 2005. Growth and management of endophytic grasses in pastoral agriculture. pp. 201-226. In: Neotyphodium in Cool-Season Grasses. Eds. Roberts, C.A.; West, C.P.; Spiers, D.E. Blackwell, Ames, IA.

Hume, D.E.; Brock, J.L. 1997. Increases in endophyte incidence in perennial ryegrass at Palmerston North, Manawatu, New Zealand. pp. 61-63. In: Neotyphodium/Grass Interactions. Eds. Bacon, C.W.; Hill, N.S. Plenum Press, New York.

Hume, D.E.; Hickey, M.J.; Tapper, B.A.; Fletcher, L.R. 2007. Degradation of endophyte alkaloids in field-dried cut ryegrass herbage. pp 167 In: Proceedings of the 6th International Symposium on Fungal Endophytes of Grasses, Grassland Research and Practice Series No. 13. New Zealand Grassland Association.

Hume, D.E.; Popay, A.J.; Cooper, B.M.; Eerens, J.P.J.; Lyons, T.B.; Pennell, C.G.L.; Tapper, B.A.; Latch, G.C.M.; Baird, D.B. 2004. Effect of a novel endophyte on the productivity of perennial ryegrass (Lolium perenne) in New Zealand. In: Proceedings of the 5th International Symposium on Neotyphodium/Grass Interactions. Eds. Kallenback; Rosenkrans; Lock University of Arkansas, Fayetteville.

Hunt, M.G.; Rasmussen, S.; Newton, P.C.D.; Parsons, A.J.; Newman, J.A. 2005. Near-term impacts of elevated CO2, nitrogen and fungal endophyte-infection on Lolium perenne L. growth, chemical composition and alkaloid production. . Plant, Cell and Environment 28: 1345-1354.

Jenkin, T.J. 1933. Interspecific and intergeneric hybrids in herbage grasses. Initial crosses. Journal of Genetics 28: 205-264.

Kain, W.M.; Wyeth, T.K.; Gaynor, D.L.; Slay, M.W. 1982. Argentine stem weevil (Hyperodes bonariensis Kuschel) resistence in perennial and hybrid ryegrasses. New Zealand Journal of Agricultural Research 25: 255-259.

Kearns, M.P. 1986. Tall fescue toxicity: an investigation of ideopathic bovine hyperthermia (IBH) in the North Auckland peninsula. Proceedings of the New Zealand Grassland Association 47: 183-186.

Keogh, R.G. 1973. Induction and prevention of ryegrass staggers in grazing sheep. New Zealand Journal of Experimental Agriculture 1: 55-57.

Keogh, R.G. 1986. Fungal distribution and livestock defoliation patterns in pasture ecosystems, and the development and control of dietary-dependent disorders. Proceedings of the New Zealand Grassland Association 47: 93-98.

Keogh, R.G.; Lawrence, T. 1987. Influence of Acremonium lolii presence on emergence and growth of ryegrass seedlings. New Zealand Journal of Agricultural Research 30: 507-510.

Keogh, R.G.; Tapper, B.A. 1993. Acremonium lolii, lolitrem $\mathrm{B}$, and peramine concentrations within vegetative tillers of perennial ryegrass. pp. 81-84. In: Proceedings of the Second
International Symposium on Acremonium/Grass Interactions. Eds. Hume, D.E.; Latch, G.C.M.; Easton, H.S. AgResearch, Palmerston North, New Zealand.

Lane, G.A.; Tapper, B.A.; Davies, E.; Hume, D.E.; Latch, G.C.M.; Barker, D.J.; Easton, H.S.; Rolston, M.P. 1997. Effect of growth conditions on alkaloid concentrations in perennial ryegrass naturally infected with endophyte. pp. 179-182. In: Neotyphodium/Grass Interactions. Eds. Bacon, C.W.; Hill, N.S. Plenum Press, New York \& London.

Latch, G.C.M. 1989. Plant improvement using endophytic fungi. pp. 1345-1346. In: Proceedings of the XVI International Grassland Congress, Nice, France.

Latch, G.C.M. 1994. Influence of Acremonium endophytes on perennial grass improvement. New Zealand Journal of Agricultural Research 37: 311-318.

Latch, G.C.M.; Christensen, M.J. 1982. Ryegrass endophyte, incidence, and control. New Zealand Journal of Agricultural Research 25: 443-448.

Latch, G.C.M.; Christensen, M.J.; Hickson, R.E. 1988. Endophytes of annual and hybrid ryegrasses. New Zealand Journal of Agricultural Research 31: 57-63.

Latch, G.C.M.; Hunt, W.F.; Musgrave, D.R. 1985. Endophytic fungi affect growth of perennial ryegrass. New Zealand Journal of Agricultural Research 28: 165-168.

Levy, E.B.; Davies, W.M. 1929. Strain investigation relative to grasses and clovers. New Zealand Journal of Agriculture 39: 1-8.

Lewis, G.C.; Ravel, C.; Naffaa, W.; Astier, C.; Charmet, G. 1997. Occurrence of Acremonium endophytes in wild populations of Lolium spp. in European countries and a relationship between level of infection and climate in France. Annals of Applied Biology 130: 227-238.

Malinowski, D.P.; Alloush, G.A.; Belesky, D.P. 2000. Leaf endophyte Neotyphodium coenophialum modifies mineral uptake in tall fescue. Plant and Soil 227: 115-126.

Malinowski, D.P.; Belesky, D.P.; Lewis, G.C. 2005. Abiotic stresses in endophytic grasses. pp. 187-199. In: Neotyphodium in Cool-Season Grasses. Eds. Roberts, C.A.; West, C.P.; Spiers, D.E. Blackwell, Ames, IA.

Milne, G.D.; Russell, A.H.; Russell, J.R.; Russell, S.W.; Russell, P.A. 1999. Experiences of ryegrass endophyte on farms on the East Coast of the North Island. pp. 33-37. In: Ryegrass Endophyte: An Essential New Zealand Symbiosis. Grassland Research and Practice Series 7. New Zealand Grassland Association.

Miyazaki, S.; Fukumura, M.; Yoshioka, M.; Yamanaka, N. 2001. Detection of endophyte toxins in the imported perennial ryegrass straw. Journal of Veterinary Medical Science 63: 1013-1015.

Moon, C.D.; Scott, B.; Schardl, C.L.; Christensen, M.J. 2000. The evolutionary origins of Epichloe endophytes from annual ryegrasses. Mycologia 92: 1103-1118.

Musgrave, D.R. 1984. Detection of an endophytic fungus of Lolium perenne using enzyme-linked immunosorbent assay (ELISA). New Zealand Journal of Agricultural Research 27: 283-288.

Oliveira, J.A.; Castro, V. 1997. Incidence and viability of Acremonium endophytes in tall fescue accessions from north Spain. Genetic Resources and Crop Evolution 44: 519-522.

Oliver, J.W. 1997. Physiological manifestations of endophyte toxicosis in ruminant and laboratory species. pp. 311-346. In: Neotyphodium/Grass Interactions. Eds. Bacon, C. W.; Hill, N. S. Plenum Press, New York.

Oliver, J.W. 2005. Pathophysiologic response to endophyte toxins. 
pp. 291-304. In: Neotyphodium in Cool-Season Grasses. Eds. Roberts, C.A.; West, C.P.; Spiers, D.E. Blackwell, Ames, IA.

Pan, J.J.; Clay, K. 2002. Infection by the systemic fungus Epichloë glyceriae and clonal growth of its host grass Glyceria striata. New Phytologist 164: 467-475.

Parish, J.A.; McCann, M.A.; Watson, R.H.; Hoveland, C.S.; Hawkins, L.L.; Hill, N.S.; Bouton, J.H. 2003a. Use of nonergot alkaloid-producing endophytes for alleviating tall fescue toxicosis in sheep. Journal of Animal Science 81: 1316-1322.

Parish, J.A.; McCann, M.A.; Watson, R.H.; Paiva, N.N.; Hoveland, C.S.; Parks, A.H.; Upchurch, B.L.; Hill, N.S.; Bouton, J.H. 2003b. Use of nonergot alkaloid-producing endophytes for alleviating tall fescue toxicosis in stocker cattle. Journal of Animal Science 81: 2856-2868.

Pennell, C.G.L.; Popay, A.J.; Ball, O.J.-P.; Hume, D.E.; Baird, D.B. 2005. Occurrence and impact of pasture mealybug (Balanococcus poae) and root aphid (Aploneura lentisci) on ryegrass (Lolium spp.) with and without infection by Neotyphodium fungal endophytes. New Zealand Journal of Agricultural Research 48: 329-337.

Popay, A.J.; Baltus, J.G. 2001. Black beetle damage to perennial ryegrass infected with AR1 endophyte. Proceedings of the New Zealand Grassland Association 63: 267-271.

Popay, A.J.; Bonos, S.A. 2005. Biotic responses in endophytic grasses. pp. 163-185. In: Neotyphodium in Cool-Season Grasses. Eds. Roberts, C.A.; West, C.P.; Spiers, D.E. Blackwell, Ames, IA.

Popay, A.J.; Hume, D.E.; Baltus, J.G.; Latch, G.C.M.; Tapper, B.A.; Lyons, T.B.; Cooper, B.M.; Pennell, C.G.; Eerens, J.P.J.; Marshall, S.L. 1999. Field performance of perennial ryegrass (Lolium perenne) infected with toxin-free fungal endophytes (Neotyphodium spp). pp. 113-122. In: Ryegrass Endophyte: An Essential New Zealand Symbiosis. Grassland Research and Practice Series 7. New Zealand Grassland Association.

Prestidge, R.A.; Gallagher, R.T. 1988. Endophyte fungus confers resistance to ryegrass: Argentine stem weevil larval studies. Ecological Entomology 13: 429-435.

Prestidge, R.A.; Popay, A.J.; Ball, O.J.P. 1994. Biological control of pastoral pests using Acremonium spp. endophytes. Proceedings of the New Zealand Grassland Association 56: 33-38.

Prestidge, R.A.; Pottinger, R.P.; Barker, G.M. 1982. An association of Lolium endophyte with ryegrass resistance to Argentine stem weevil. Proceedings of the 35th N.Z. Weed and Pest Control Conference 119-122.

Rasmussen, S.; Parsons, A.J.; Bassett, S.; Christensen, M.J.; Hume, D.E.; Johnson, L.J.; Johnson, R.D.; Simpson, W.R.; Stacke, C.; Voisey, C.R.; Xue, H.; Newman, J.A. 2007. High nitrogen supply and carbohydrate content reduce fungal endophyte and alkaloid concentration in Lolium perenne. New Phytologist 173: 787-797.

Ravel, C.; Astier, C.; Balfourier, F.; Charmet, G. 1997a. Acremonium endophytes of perennial ryegrass (Lolium perenne) in France. pp. 17-18. In: Proceedings of the XVIII International Grassland Congress 13.

Ravel, C.; Charmet, G.; Balfourier, F. 1995. Influence of the fungal endophyte Acremonium lolii on agronomic traits of perennial ryegrass in France. Grass and Forage Science 50: 75-80.

Ravel, C.; Courty, C.; Coudret, A.; Charmet, G. $1997 \mathrm{~b}$. Beneficial effects of Neotyphodium lolii on the growth and the water status in perennial ryegrass cultivated under nitrogen deficiency or drought stress. Agronomie 17: 173-181.

Read, J.C.; Camp, B.J. 1986. The effect of the fungal endophyte
Acremonium coenophialum in tall fescue on animal performance, toxicity, and stand maintenance. Agronomy Journal 78: 848-850.

Reed, K.F.M.; McFarlane, N.M.; Walsh , J.R. 2001. Seasonal alkaloid concentrations in perennial ryegrass dairy pasture. Proceedings of the 10th Australian Agronomy Conference, online: www.regional.org.au/au/asa/2001/.

Reed, K.F.M.; Scrivener, C.J.; Rainsford, K.A.; Walker, L.V. 2005. Neotyphodium research and application in Australia. pp. 43-54. In: Neotyphodium in Cool-Season Grasses. Eds. Roberts, C.A.; West, C.P.; Spiers, D.E. Blackwell, Ames, IA.

Richardson, M.D.; Chapman, G.W., Jr.; Hoveland, C.S.; Bacon, C.W. 1992. Sugar alcohols in endophyte-infected tall fescue under drought. Crop Science 32: 1060-1061.

Richardson, M.D.; Hoveland, C.S.; Bacon, C.W. 1993. Photosynthesis and stomatal conductance of symbiotic and nonsymbiotic tall fescue. Crop Science 33: 145-149.

Roberts, C.; Kallenbach, R.; Hill, N. 2002. Harvest and storage method affects ergot alkaloid concentration in tall fescue. Crop Management 2002: 1-3.

Rolston, M.P.; Agee, C.S. 2007. Delivering quality seed to specification - the USA and NZ novel endophyte experience. pp 229 In: Proceedings of the 6th International Symposium on Fungal Endophytes of Grasses, Grassland Research and Practice Series No. 13. New Zealand Grassland Association.

Rolston, M.P.; Hare, M.D.; Moore, K.K.; Christensen, M.J. 1986. Viability of Lolium endophyte fungus in seed stored at different moisture contents and temperatures. New Zealand Journal of Experimental Agriculture 14: 297-300.

Rowan, D.D.; Shaw, G.J. 1987. Detection of ergopeptine alkaloids in endophyte-infected perennial ryegrass by tandem mass spectrometry. New Zealand Veterinary Journal 35: 197-198.

Schmidt, S.P.; Osborn, T.G. 1993. Effects of endophyte-infected tall fescue on animal performance. Agriculture, Ecosystems and Environment 44: 233-262.

Spiers, D.E.; Evans, T.J.; Rottinghaus, G.E. 2005. Interaction between thermal stress and fescue toxicosis: animal models and new perspectives. pp. 243-270. In: Neotyphodium in Cool Season Grasses. Eds. Roberts, C.A.; West, C.P.; Spiers, D.E. Blackwell, Ames, IA.

Stamm, M.M.; DelCurto, T.; Horney, M.R.; Brandyberry, S.D.; Barton, R.K. 1994. Influence of alkaloid concentration of tall fescue straw on the nutrition, physiology, and subsequent performance of beef steers. Journal of Animal Science 72: 1068-1075.

Stewart, A.V. 2006. Genetic origins of perennial ryegrass (Lolium perenne) for New Zealand pastures. pp. 55-61. In: Advances in Pasture Plant Breeding. Grassland Research and Practice Series 12. New Zealand Grassland Association.

Sutherland, B.L.; Hoglund, J.H. 1989. Effect of ryegrass containing the endophyte (Acremonium lolii), on the performance of associated white clover and subsequent crops. Proceedings of the New Zealand Grassland Association 50: 265-269.

Thom, E.R.; Waugh, C.D.; Minnee, E.M.K.; Waghorn, G.C. 2007. A new generation ryegrass endophyte - the first results from dairy cows fed AR37. pp 293 In: Proceedings of the 6th International Symposium on Fungal Endophytes of Grasses, Grassland Research and Practice Series No. 13. New Zealand Grassland Association.

Thom, E.R.; Clark, D.A.; Waugh, C.D. 1999. Endophyte and dairy production in New Zealand: experience at the Dairying Research Corporation. pp. 39-44. In: Ryegrass Endophyte: An 
Essential New Zealand Symbiosis. Grassland Research and Practice Series 7. New Zealand Grassland Association.

Thompson, R.W.; Fribourg, H.A.; Waller, J.C.; Sanders, W.L.; Reynolds, J.H.; Phillips, J.M.; Schmidt, S.P.; Crawford, R.J., Jr.; Allen, V.G.; Faulkner, D.B.; Hoveland, C.S.; Fontenot, J.P.; Carlisle, R.J.; Hunter, P.P. 1993. Combined analysis of tall fescue steer grazing studies in the Eastern United States. Journal of Animal Science 71: 1940-1946.

Ussher, G. 2003. Northland's pasture toxin project. pp. 62-64. In: New Zealand Large Herds Association, 34th annual conference. New Zealand Large Herds Association Inc., Paihia.

Watson, R.H.; Keogh, R.G.; McDonald, M.F. 1999. Ewe reproductive performance and growth rate of sucklinglambs on endophyte-infected perennial ryegrass pasture. pp. 19-26. In: Ryegrass Endophyte: An Essential New Zealand Symbiosis. Grassland Research and Practice Series 7. New Zealand Grassland Association.

Watson, R.H.; McCann, M.A.; Parish, J.A.; Hoveland, C.S.; Thompson, F.N.; Bouton, J.H. 2004. Productivity of cow-calf pairs grazing tall fescue pastures infected with either the wildtype endophyte or a nonergot alkaloid-producing endophyte strain, AR542. Journal of Animal Science 82: 3388-3393.

Welty, R.E.; Azevedo, M.D.; Cooper, T.M. 1987. Influence of moisture content, temperature, and length of storage on seed germination and survival of endophytic fungi in seeds of tall fescue and perennial ryegrass. Phytopathology 77: 893-900.

Welty, R.E.; Craig, A.M.; Azevedo, M.D. 1994. Variability of ergovaline in seeds and straw and endophyte infection in seeds among endophyte-infected genotypes of tall fescue. Plant Disease 78: 845-849.

West, C.P.; Izekor, E.; Turner, K.E.; Elmi, A.A. 1993. Endophyte effects on growth and persistence of tall fescue along a watersupply gradient. Agronomy Journal 85: 264-270.

Wheatley, W.M.; Hume, D.E.; Kemp, H.W.; Monk, M.S.; Lowe, K.F.; Popay, A.J.; Baird, D.B.; Tapper, B.A. 2003. Effects of fungal endophyte on the persistence and productivity of tall fescue at 3 sites in eastern Australia. Proceedings of the 11th Australian Agronomy Conference: CDROM ISBN 0-97503130-9. www.regional.org.au/au/asa

Widdup, K.H.; Ryan, D.L. 1992. Forage potential of wild populations of perennial ryegrass collected from southern New Zealand farms. Proceedings of the New Zealand Grassland Association 54: 161-165.

Yates, S.G. 1962. Toxicity of tall fescue forage: a review. Economic Botany 16: 295-303.

Yates, S.G.; Plattner, R.D.; Garner, G.B. 1985. Detection of ergopeptine alkaloids in endophyte infected, toxic Ky-31 tall fescue by mass spectrometry/mass spectrometry. Journal of Agricultural and Food Chemistry 33: 719-722. 